\title{
The International Protection of Vulnerable Groups during Armed Conflicts
}

\section{Reagr Farhad Muhammadamin}

Department of Legal Administrative, Erbil administrative technical institute, Erbil

Polytechnic University

PhD student Department of law, Faculty of law, Political Science \& Management, Soran

University, Erbil, Iraq

Regrf82@gmail.com

\section{Bryar Sherko Baban}

Department of law, faculty of law, Salahaddin University, Erbil, Iraq

bryar.baban@su.edu.krd

\section{Article History:}

Received: 4/6/2020

Accepted: 28/7/2020

Published: Summer 2020

This is a research drawn

from the doctoral thesis

\section{Keywords:}

vulnerable groups, protection, armed conflict, international

humanitarian law, united nation organization

\section{ABSTRACT}

This research provides an overview of the various frameworks for protecting the status of vulnerable groups impacted by armed conflict. International humanitarian law and United Nations, various institutions and agencies, and non-governmental organizations aim to resolve armed conflict situations. Humanitarian action, however, unattached to any political agenda and balancing security and assistance, is often the only solution for the plight of armed conflict victims. Thus, this article deals with the mechanism to protect vulnerable groups. There are many conventions available in the covenant to protect them. I will discuss the mechanism in which the international conventions and resolutions with some former cases have clarified its recognizing a certain subject as vulnerable groups they have to protection. 
Doi:

10.25212/lfu.qzj.5.3.37

\section{Introduction}

Throughout history vulnerable groups have been subjected to discriminative policy, rape, killing, and sexual violence in armed conflict whether international or noninternational. In fact, one of the major contributing factors to the outbreak of the First World War in 1914 was the problem of vulnerable groups in South-East Europe. In order to the vulnerable groups not to be subjected to further discrimination and not to targeted during armed conflict. The international community-after the First World War-or that reason formally included within the international legal framework an international treaty to protect vulnerable group's rights and states had to assume obligations for this protection.

\section{Research Background}

The discriminative policies have become the main source of internal and international conflicts. This shows that the armed conflicts against vulnerable groups in many countries are not standing alone. For example, in the former Yugoslavia, similar conflicts have occurred and handled appropriately by the international intervention through United Nations Security Council (UNSC). The case of former Yugoslavia shows that when the conflicts turn to confrontation, and armed conflicts and atrocities have been committed against vulnerable groups, it has been the immediate reaction of the UNSC to adapt resolution, and warn all parties of conflicts to comply fully with stated resolution. Then, the UNSC took next step by establishing a tribunal in the form of ad hoc tribunal; International Criminal Tribunal for the former Yugoslavia (ICTY), in order to bring the perpetrators of recognized international crimes to justice.

About 5 percent of the victims were vulnerable groups during the First World War. In World War II, the figure was 50 percent. Nearly 90 percent of the victims in today's 


\section{QALAAI ZANISTSCIENTIFIC JOURNAL \\ A Scientific Quarterly Refereed Journal Issued by Lebanese French University - Erbil, Kurdistan, Iraq \\ Vol. (5), No (3), Summer 2020 \\ ISSN 2518-6566 (Online) - ISSN 2518-6558 (Print)}

armed conflict are vulnerable groups, most of them women and children, (U C Jha and K Ratnabali, 2017, p. 246) consider the following facts:

In Iraq, 18,802 vulnerable groups were killed and 36,245 were injured in the unarmed conflict from January 1, 2014 to October 2015. The actual number of vulnerable group's victims may be much greater than reported casualties. In addition, it is unclear how many people have died as a result of the indirect effects of the war, such as not getting enough food, water or medical care. Infants, pregnant women, the disabled and the elderly remained particularly vulnerable, (U C Jha and Ratnabali, 2017, p. 246).

Today, vulnerable groups account for between 80 and 90 percent of war victims. Moreover, women and children make up 80 percent of the violation and refugee, and are therefore the most vulnerable. In refugee camps, the death rate among women is three times higher than for men, (Veronique Zanetti, Women, 2007, p. 233)

Throughout the fighting, ISIS fighters have committed systematic violations - such as executions, sexual slavery, torture and forced transfer - that may lead to war crimes, crimes against humanity and genocide. During the coalition airstrikes against ISIS, hundreds of vulnerable groups were killed, (Global Centre for the Responsibility to Protect, 2020).

Moreover, the available laws have failed to protect these groups during the conflict as noted Kosovo, Rwanda, Cambodia, and Kurdistan Region and more recently with ISIS is both Iraq and Syria after 2014.

\section{Problem Statement}

The recent history shows that instruments have faced many discriminative and violence due to their vulnerable as an inferior to the rest of the society. They have been targeted because they are weaker and have different religious, ethnicity, nationality, identity, cultural or linguistic views. 


\section{QALAAI ZANISTSCIENTIFIC JOURNAL \\ A Scientific Quarterly Refereed Journal Issued by Lebanese French University - Erbil, Kurdistan, Iraq \\ Vol. (5), No (3), Summer 2020 \\ ISSN 2518-6566 (Online) - ISSN 2518-6558 (Print)}

There is a growing trend of massacre and violation against vulnerable groups; this has resulted in recognized international crimes being committed against them. These vulnerable groups have been subjected to crimes of genocide, ethnic, religious, and language cleansing, and being displaced in millions by force in many parts of the world.

Due to increasing violation against vulnerable groups, the international communities in many instances have intervened to protect these vulnerable groups. This has become one of the main issues of international law and order.

\section{Research Questions}

\section{The question of this thesis tries to address:}

1. Do applicable and available legal mechanisms to protect the vulnerable groups in armed conflict?

2. How does the law protect the vulnerable groups in armed conflicts?

\section{Research Objective of the Study}

The main objectives of this research are:

1. Attempts to address the above mentioned research questions in order to understand and analyze the protection of vulnerable groups in armed conflict. It also attempts to examine the relevant international law in different fields to compare the legal theory and the practice of states on this matter.

2. Attempts to identify a legal mechanism, national and international instrument to be able to adequately protect vulnerable groups in armed conflict.

\section{Significant of the Study}

Armed groups target vulnerable groups often due to the fact that they are different from them in respect of ethnic, nationality, religious, cultural identity and/or language. For many years, in many parts of the world, vulnerable groups have 


\section{QALAAI ZANISTSCIENTIFIC JOURNAL \\ A Scientific Quarterly Refereed Journal Issued by Lebanese French University - Erbil, Kurdistan, Iraq \\ Vol. (5), No (3), Summer 2020 \\ ISSN 2518-6566 (Online) - ISSN 2518-6558 (Print)}

suffered grievances and discriminative behavior. This is because of lack of guarantees, mechanisms and regulation to protect them from the attacks of the army groups.

\section{Research Methodology}

This research critically analysis the legal protection of vulnerable groups in armed conflict and their status in international law. The research uses primary and secondary sources as a legal doctrine to address the research questions. The study investigates the state practice and the courts' jurisprudence to examine closely the relevant behavior of actors involved in such armed conflict and their disobedience to the applicable international instrument. However, the study also critically analyses and evaluates a number of secondary legal sources, either as hardcopies or electronic materials. Such sources include textbooks, paper journals.

\section{Article Outline}

In order to address the article questions, this study is divided into three main sections, as well as introduction and conclusion. Section one discusses the definition and concept of vulnerable groups, section two discusses the protections of vulnerable groups under International Humanitarian law section three also discusses the protections of vulnerable groups by united nation organization.

\section{Section one: The definition and concept of vulnerable groups}

The individuals and groups that the conventions have recognized as vulnerable are subject into protections in circumstance armed conflicts. Amongst others victims are children and women qualified as vulnerable by the international law. This section will zoom in on the individuals and vulnerable groups that the international law has recognized as vulnerable within the context of its conventions. The unit will begin by showing of definitions and concept of the vulnerable groups and individuals that the international covenant has recognized as vulnerable with aim of being able to protect them. 


\section{QALAAI ZANISTSCIENTIFIC JOURNAL \\ A Scientific Quarterly Refereed Journal Issued by Lebanese French University - Erbil, Kurdistan, Iraq \\ Vol. (5), No (3), Summer 2020 \\ ISSN 2518-6566 (Online) - ISSN 2518-6558 (Print)}

\subsection{Definitions of vulnerable groups}

A dictionary is a great place to begin grasping the plain meaning of the vulnerable adjective. This term, according to Merriam-Webster, means "capable of being physically or emotionally wounded" or "open to attack or damage." These definitions are rooted in the etymology of the term vulnerable which comes from the Latin terms "vulnerare" and "vulnus", meaning, respectively, "to wound" and "wound." Then, by observation, the word weakness can be described as referring to a situation that affects a person or may be affected by physical or emotional damage. In other words, vulnerability means actual or potential damage, (Merriam dictionary, 2019). Knowledge as such weakness is universal in the sense that it is inevitable in everyone's life or can happen in everyone's life. Approximately everyone faced vulnerability as emotional damage after losing a loved one, despite our physicality.

Typically, these words are used to identify cases of physical and psychological weakness, disability, illness, and potential or immediate threat. Sensitive and vulnerable conditions thus determine people's plight in abusive and emotional reactions (Ingrid Nifosi-Sutton, 2017, p. 4).

\subsection{Concept of vulnerable groups}

The legal notion of "vulnerable groups" arose, despite the lack of clarity although one of the most effective efforts to identify vulnerable groups was discovered in the Brasilia Regulations on Access to Justice for Vulnerable Groups.: (Francesca Ippolito and Sara Iglesias Sánchez, 2015, p.1).

"Vulnerable people are defined as those who, due to reasons of age, gender, physical or mental state, or due to social, economic, ethnic and/or cultural circumstances, find it especially difficult to fully exercise their rights before the justice system as recognized to them by law. The following may constitute causes of vulnerability: age, disability, belonging to indigenous communities or minorities, victimization, migration and internal displacement, poverty, gender and deprivation of liberty." 


\section{QALAAI ZANISTSCIENTIFIC JOURNAL \\ A Scientific Quarterly Refereed Journal Issued by Lebanese French University - Erbil, Kurdistan, Iraq \\ Vol. (5), No (3), Summer 2020 \\ ISSN 2518-6566 (Online) - ISSN 2518-6558 (Print)}

Although human rights are involved in protecting the fundamental rights of vulnerable and disadvantaged individuals and organizations, there is no basic human rights theory or framework to do so. The criteria for recognition of vulnerable and disadvantaged populations, the definition of approved vulnerability, or a normal list of these communities are not agreed. Human rights bodies usually deal on an ad hoc basis with vulnerable and disadvantaged groups (Chandrima Chatterjee \& Gunjan Sheoran, 2007).

A relatively extensive list prepared by the Icelandic Center for Human Rights identifies 13 organizations that need unique protection: “(1) women and girls; (2) children; (3) refugees; (4) internally displaced persons; (5) stateless persons; (6) national minorities; (7) indigenous peoples; (8) migrant workers; (9) disabled persons; (10) elderly persons; (11) HIV positive persons and AIDS victims; (12) Roman/Gypsies/Sinti; and (13) lesbian, gay, and transgender people." A list of vulnerable groups residing in India divides them into five categories: (1) vulnerable groups facing structural discrimination (women, scheduled castes, Dalits [Untouchables], Scheduled Tribes); (2) children and the aged; (3) those vulnerable due to disability; (4) those vulnerable due to migration; and (5) those with vulnerability due to stigma and discrimination (people living with HIV/AIDS and sexual minorities), (Audrey R. Chapman \& Benjamin Carbonetti, 2011, p. 686-707).

The commitment of human rights to the protection of the basic rights of vulnerable and disadvantaged groups requires a set of human rights schemes at the United Nations. It has resulted in a series of specific human rights tools and mechanisms. The latest is the International Convention on the Rights of Persons with Disabilities (Audrey R. Chapman \& Benjamin Carbonetti, 2011, p. 686-707). It was preceded by the International Convention on the Elimination of All Forms of Racial Discrimination1969, the Convention on the Elimination of All Forms of Discrimination against Women1979, the Convention on the Rights of the Child 1989, and the International Convention on the Protection of the Rights of All Migrant Workers and Members of Their Families 1990 (Alice Edwards, 2009, p. 8). 


\section{QALAAI ZANISTSCIENTIFIC JOURNAL \\ A Scientific Quarterly Refereed Journal Issued by Lebanese French University - Erbil, Kurdistan, Iraq \\ Vol. (5), No (3), Summer 2020 \\ ISSN 2518-6566 (Online) - ISSN 2518-6558 (Print)}

According to the Human Rights Committee of UN discussed, "groups" relate to any group of people associated with their situation, (Audrey R. Chapman \& Benjamin Carbonetti, 2011, p. 686-707). This assessment distinguishes between two types of status: static or variable state. Usually, but not always, a fixed state is something that is obtained by birth and is considered immutable. The groups considered to be consistent in this assessment are: females; children; youth; older persons; persons with disabilities; and minorities of race, ethnicity and religion. On the other hand, a changing situation is something that people get because they belong to a socioeconomic group. Variable categories include: immigrant staff, single mothers, displaced persons, the unemployed and the poor. As an example of how the Committee refers to the bonds granted to Iraq in 1997, the Committee identifies the issue of financial sanctions in Iraq and notes that "these policies have a significant impact on the innocent population, especially the weak and poor, especially women and children, (U.N. Doc. E/C.12/I/Add.17 (1997).

Section two: The protection of vulnerable groups under international humanitarian law

The idea of "protection of vulnerable groups", as used in the dictionary of international humanitarian law (merriam-webster, dictionary) has a clear significance in the context of peacekeeping operations, and is known as the thematic priorities of the United Nations Security Council. Under international humanitarian law, protection of vulnerable groups essentially includes all of those obligations that aim to reduce the harm to vulnerable groups by limiting the means and methods of warfare on the part of the parties. In other words, there are restrictions on parties 'actions to minimize the impact of hostilities. There is also a set of positive responsibilities, especially in terms of ensuring humanitarian access and the delivery of humanitarian assistance, (Haidi Willmot, Ralph Mamiya, Scott Sheeran, and Marc Weller, 2016, p. 163). 


\section{QALAAI ZANISTSCIENTIFIC JOURNAL \\ A Scientific Quarterly Refereed Journal Issued by Lebanese French University - Erbil, Kurdistan, Iraq \\ Vol. (5), No (3), Summer 2020 \\ ISSN 2518-6566 (Online) - ISSN 2518-6558 (Print)}

The main sources of international humanitarian law applicable to the protection of vulnerable groups are the four Geneva Conventions of 1949, which were unanimously ratified (Ursula Kilkelly and Ton Liefaard, 2019, p. 520).

\subsection{Protection vulnerable groups in conflicts in two different situations:}

a) In armed conflicts, vulnerable groups need protection if they fall into the hands of "enemy forces". For instant these hostile armed forces may arrest, ill-treat, threaten, confiscate their property, or not give them any food or medical supplies. Such conditions do not occur when vulnerable groups are subjected to violent military conflict, but when the armed forces communicate with vulnerable groups who are loyal to the "enemy" in the background of the ongoing hostilities. This usually happens outside of active war zones. In such cases, the law seeks to protect vulnerable people from unlawful actions by competing authorities under their influence. This control may flow primarily from a vulnerable group's presence on the territory of an enemy combatant or within the territory occupied by an anticombatant. In these cases, the Fourth Geneva Convention aims to defend the most vulnerable, (Robert Kolb and Richard Hyde, 2008, p. 221).

b) In wars, unsafe groups are targets; even vulnerable groups need protection during the active phase of the war. While they are not in their possession directly or under the influence of the enemy, they may face bomb attacks on their cities or may suffer disproportionate damage from attacks that do not sufficiently take into account the collateral damage caused by such attacks on vulnerable groups. Laws aimed at protecting vulnerable groups from the aftermath of war (Hague Regulations, Art 25 (1907) are mainly found in The Hague Regulations and Additional Protocol I, (Protocol Additional I, (1977) 1125).

International humanitarian law, in addition to other treaties, is codified in the 1949 Geneva Conventions and their two additional protocols. Each of the High Contracting Parties to the Conventions bears collective responsibility for ensuring compliance. Popular Article 1 of the agreements (Additional protocol I, Art. 1 (1977) mandates all parties "to respect and to ensure respect for the present Convention in all 


\section{QALAAI ZANISTSCIENTIFIC JOURNAL \\ A Scientific Quarterly Refereed Journal Issued by Lebanese French University - Erbil, Kurdistan, Iraq \\ Vol. (5), No (3), Summer 2020 \\ ISSN 2518-6566 (Online) - ISSN 2518-6558 (Print)}

circumstances," a duty reinforced by Additional Protocol I. The International Court of Justice has described this obligation as a derivative one "from the general principles of humanitarian law to which the Conventions merely give specific expression" Nicaragua v. United States of America, 1986, p.220). This means that the obligations defined in common Article 1 are customary international law, meaning that they are binding on all states, including states not party to the agreements, (Geneva Conventions I, Common Article 1 (1949).

In conclude, the Geneva Conventions and the Additional Protocols provide that women and children must be evaluated and protected from sexual violence, rape, killing and forced prostitution or any other type of inappropriate abuse. It is this part of the law that must be confirmed, published and implemented during situations of armed conflict in order to enhance their security. The ICRC, for its part, has promised to focus its special attention on this particular issue.

\subsection{General Protection of the vulnerable groups against the Effects of Hostilities}

Since most women and children are exposed in armed conflict as vulnerable groups, the principle of non-combatant immunity is international humanitarian law, which has the greatest potential to protect them during the actual conduct of hostilities, (Judith Gail Gardam and Michelle J Jarvis, 2011, p.85). In short, the standard requires parties to an armed conflict to distinguish between vulnerable groups and fighters at all times and between weak groups and military objectives and to focus their operations on the latter only, (Geoffrey Best, 1994, p.115).

Article 48 of Protocol I stipulates the codification of the usual rule that "parties to the conflict shall at all times distinguish between the vulnerable groups and combatants and between vulnerable groups objects and military objectives and accordingly shall direct their operations only against military objectives" (Judith Gail Gardam, 1992, p. 46-47). In Article 48, the broad formulation of the base is not sufficient to provide adequate protection for vulnerable groups from the effects of hostilities. For example, even if opposing parties comply with Article 48 and restrict attacks on military targets, damage to the targets of vulnerable side groups may be 


\section{QALAAI ZANISTSCIENTIFIC JOURNAL \\ A Scientific Quarterly Refereed Journal Issued by Lebanese French University - Erbil, Kurdistan, Iraq \\ Vol. (5), No (3), Summer 2020 \\ ISSN 2518-6566 (Online) - ISSN 2518-6558 (Print)}

unacceptable. Accordingly, the basic rule in Article 48 is supplemented by specific rules in Articles 51 and 57 aimed at explaining how to control the level of damage to vulnerable group's objects, (Judith Gail Gardam and Michelle J Jarvis, 2011, p. 69).

Article 51 of protocol prohibits direct attacks on vulnerable groups; acts or threats of violence with the primary objective of spreading terror among vulnerable groups; and revenge against vulnerable groups. Perhaps the most important aspect of the 1977 additional rules protecting vulnerable groups from the means and methods of warfare is the prohibition of indiscriminate attacks in order to reduce additional vulnerable group's casualties Indiscriminate attacks (Additional Protocol I, 1977 Art 51 (2) and (6). "Those who do not target a specific military objective; or that use a method or method of combat that cannot be directed at a specific military objective"; or "that use a method or means to combat its effects that cannot be restricted as required by this protocol; therefore, in each case In these cases, it is normal to hit military targets, vulnerable groups or civilian objects without discrimination" (Additional Protocol I, 1977, Art 51(4).

The protocol also prohibits intentional use as a shield of military operations for vulnerable groups. Various other obligations are imposed on the conflicting parties to protect vulnerable groups, such as taking precautions to place or locate objects of vulnerable groups near military objectives, (Additional Protocol I, 1977, Arts 57-58(b) and the use of vulnerable groups to protect military objectives, (Additional Protocol I, 1977, Art 51(7).

\subsection{The ICRC}

The International Committee of the Red Cross (ICRC) is a neutral, impartial and independent body whose purely humanitarian mission is to protect the victims and dignity of victims of conflict and other attacks and to provide them with assistance. This directs and coordinates the humanitarian operations carried out in armed conflicts and other aggressions by the humanitarian Red Cross and Red Crescent Movement. It also aims to alleviate suffering by applying and promoting international humanitarian law and universal humanitarian principles. The ICRC, founded in 1863, 


\section{QALAAI ZANISTSCIENTIFIC JOURNAL \\ A Scientific Quarterly Refereed Journal Issued by Lebanese French University - Erbil, Kurdistan, Iraq \\ Vol. (5), No (3), Summer 2020 \\ ISSN 2518-6566 (Online) - ISSN 2518-6558 (Print)}

is at the heart of the movement, (International Review of the Red Cross humanitarian debate, 2015, p.2).

The ICRC played a special role in establishing international humanitarian law. It carried out awareness-raising activities on international humanitarian law and worked towards its implementation. It is not the only organization that has sought to facilitate legal changes in the field of human security and human rights in armed conflict, (David P. Forsythe and Barbara Ann J. Rieffer-Flanagan, 2007, p.38).

A wide range of operations in situations of armed conflict at the ICRC can be classified into three main categories: preventive, operational and post-conflict. The ICRC works with the authorities and all arms carriers to raise awareness of their legal responsibilities under international humanitarian law in an effort to avoid suffering by ensuring compliance with this rule. Efforts to protect and assist victims of armed conflict may take many forms, including the provision of basic services such as food, water, shelter, medical care and other vital products. Specific assistance can be provided to persons at particular risk, such as detainees. If contacts are broken or families separated due to the war, the ICRC aims to restore contact and family reunification, often long after the fighting has ended, (Terry D. Gill , 2014, p.6).

The objectives of the draft protocol of the Second Protocol of the International Committee of the Red Cross are three aspects: first, to modernize existing humanitarian law regarding internal armed conflict, and to address any shortcomings, especially with regard to the conduct of war and methods and means of warfare; second, to explain the scope of humanitarian law in relation to internal armed conflicts, Especially with regard to minimum issues. The objective of the ICRC's security was not vulnerable groups, but medical assistance was the primary means. But over time, the ICRC's mandate expanded to include other groups of people, as well as other means of defense, (Lindsay Moir, 2004, p. 91).

However, the ICRC is famous for providing humanitarian assistance, which is a right enshrined in conventions and protocols. The States Parties shall, as provided for in Article 81 of Protocol I: "grant to the International Committee of the Red Cross all 


\section{QALAAI ZANISTSCIENTIFIC JOURNAL \\ A Scientific Quarterly Refereed Journal Issued by Lebanese French University - Erbil, Kurdistan, Iraq \\ Vol. (5), No (3), Summer 2020 \\ ISSN 2518-6566 (Online) - ISSN 2518-6558 (Print)}

facilities within their power so as to enable it to carry out the humanitarian functions assigned to it by the Conventions and this Protocol in order to ensure protection and assistance to the victims of conflicts; the International Committee of the Red Cross may also carry out any other humanitarian activities in favour of these victims". ( Emily Crawford and Alison Pert, 2015, p. 520).

The study of legal protection for victims of armed conflict and how it has evolved over time should take into account the nature of aid operations on the ground. Regardless of progress or not, unprecedented financial and operational resources in the legal field and a global network of humanitarian actors have revolutionized the effective protection of victims of armed conflict. The law may have ambitious and comprehensive argument, but in practice, the feasibility and scope of operations always determine the actual application of the law.

Humanitarian assistance can be provided during the conflict by the government where the conflict occurs or by the International Red Cross, which also includes the International Committee of the Red Cross. The presence of the International Committee of the Red Cross is recognized in the four Geneva Conventions of 1949 and in its three additional protocols, (Gerald Alditya Bunga, 2017, p. 13).

The ICRC operates under the principle of neutrality, neutrality and independence and does not stand by any country (or a group of non-states) in times of armed conflict; it is not part of any political or governmental influence; its sole duty is to facilitate and reinforce compliance with the laws of armed conflict and assist the parties to the conflict. The ICRC also considers the general "right of initiative" - the right to provide its services to all parties to any conflict, whether international or noninternational, on matters that the ICRC considers within its competence, (Hans-Peter Gasser, 2016).

Over the years, the ICRC has participated in its attempts to minimize the horrors of women's conflict. As mentioned above, its importance is expressed in the provisions of the Geneva Conventions and the two Additional Protocols. These laws prohibit the above-mentioned acts of violence against women in unambiguous terms and declare 


\section{QALAAI ZANISTSCIENTIFIC JOURNAL \\ A Scientific Quarterly Refereed Journal Issued by Lebanese French University - Erbil, Kurdistan, Iraq \\ Vol. (5), No (3), Summer 2020 \\ ISSN 2518-6566 (Online) - ISSN 2518-6558 (Print)}

that they are illegal. All that is needed is the collective will of the international community to fully implement those provisions. The primary responsibility for doing so rests with the opposition armed groups. Laws must be followed and appropriate steps have to be taken to deter sexual violence; they must bring victims to justice if they commit these crimes.

For example, forty-one ICRC delegates visited only 524 prisoners during World War I. throughout World War II, there were 11,000 visits by 150 detention delegates. More than 750,000 prisoners received visits to the ICRC in 2013 alone. Today's organizational and financial flexibility actually allows the defense provided for in international humanitarian law to be applied more widely. Over its 150 years of existence, the International Committee of the Red Cross has proven its mastery of its unique role as an agency covering its mandate to establish law and ground operations. The ICRC stretches to the ground when organizational expansion is reasonable within the legal framework. The company calls for this when the legal structure needs clarification. The ICRC continues to protect and support victims of conflict, whether in the legal or regulatory field, (Peter Maurer, 2014, p. 7).

In international armed conflicts, the ICRC has the authority to visit prisoners of war and detained vulnerable groups persons, and has the right to initiate States parties to the 1949 Geneva Conventions and their additional protocols that are bound to recognize the humanitarian activities of the International Committee of the Red Cross (Article 126 of the (Third) Geneva Convention) 1949 and Article 143 From the Fourth Geneva Convention: 1949, Geneva Convention IV, 1949, Articles 10 and 11).

Moreover, Article 81 of Additional Protocol I states that states parties to the conflict must provide the ICRC with all the means at their disposal to allow the International Committee of the Red Cross to carry out the humanitarian tasks assigned to it by the Geneva Conventions and additional protocols to ensure protection and assist victims of the conflict, (Gerald Alditya Bunga, 2017, p. 14).

In non-international armed conflicts, the ICRC will provide its services to the opposing parties. In particular, the ICRC can provide its services to the warring parties with a 


\section{QALAAI ZANISTSCIENTIFIC JOURNAL \\ A Scientific Quarterly Refereed Journal Issued by Lebanese French University - Erbil, Kurdistan, Iraq \\ Vol. (5), No (3), Summer 2020 \\ ISSN 2518-6566 (Online) - ISSN 2518-6558 (Print)}

view to visiting persons deprived of their liberty due to the armed conflict, in order to verify the conditions of their detention and establish contacts between them and their families, (Geneva Convention, Common, 1949, Article 3).

The ICRC may also be asked to provide assistance in certain violent circumstances, as defined in the statutes of the Red Cross and International Red Crescent (art. 5, paragraph (2), letter (d), statute of the Red Cross and Red Crescent). In this case, the ICRC will provide its assistance without interfering in the internal affairs of the state concerned or giving any group the status of these offers.

In protecting people in armed conflict the ICRC seeks to minimize the dangers that threaten such people, to prevent and stop abusive treatment against them, to keep their rights in mind and their voices heard, and to provide them with assistance. To do this, the ICRC takes two ways: first, to stay near the victims of conflict and violence, second, conduct closed dialogue with the parties involved, both state and non-state, (Gerald Alditya Bunga, 2017, p. 14).

To conclude, as mentioned above, in addition to the Fourth Geneva Convention and the two protocols, the almost universally adopted conventions, protocols and treaties relating to the protection of vulnerable groups that require states parties to "take all feasible measures to ensure protection and care of children who are affected by an armed conflict," in compliance with their obligations under international humanitarian law (Convention on the Rights of the Child, 1989, Art. 38(4).

The International Committee of the Red Cross voiced concern about the issue of wartime for vulnerable groups such as children and women because they are vulnerable. Vulnerable groups at risk are more and more at risk today. The war demonstrated that the health of children and women because of their gender and sex is not guaranteed by the government. There is a close relationship between the effects on the two groups.

Different law enforcement agencies have different purposes. Organizing the conduct of war is one of the main objectives of international humanitarian law. By doing this, 


\section{QALAAI ZANISTSCIENTIFIC JOURNAL \\ A Scientific Quarterly Refereed Journal Issued by Lebanese French University - Erbil, Kurdistan, Iraq \\ Vol. (5), No (3), Summer 2020 \\ ISSN 2518-6566 (Online) - ISSN 2518-6558 (Print)}

it gives vulnerable groups valuable security. The legislation provides adequate security, whether in conditions of foreign or non-international armed conflicts.

\section{Section three: The Protection of vulnerable groups by United Nation organization}

It is clear that the United Nations and their organizations have a responsibility to protect all peoples from mass atrocities in times of war. This section tries to address some instruments through their organization systems to protect vulnerable groups as following.

\subsection{Security Council and Vulnerable groups}

The Security Council is a legislative body, and the circumstances in which it operates are determined by political considerations. For example, the development of both the International Criminal Tribunal for the former Yugoslavia and the International Criminal Tribunal for Rwanda is considered by many to be an attempt to uncover the primary failure of the United Nations to implement its position on conflict prevention and effective management (Judith G. Gardam and Michelle J. Jarvis, 2011, p. 226-7). Culture and ethnicity were also described as important determinants of the Security Council's response ( Payam Akhavan, 1996, p. 501-510).

An overview of the events surrounding the development of the International Criminal Tribunal for the Former Yugoslavia and the International Criminal Tribunal for Rwanda shows that gender-based violence is also a factor. Although the conscience of the international community was shaken by the sexual assault of Bosnian women, sexual violence against women in Rwanda was ignored. Sex also played a role in the subsequent research of the International Criminal Tribunal for the former Yugoslavia and the International Criminal Tribunal for Rwanda (Anne Orford, 1996, p. 373).

In terms of humanitarian, the UN Security Council has grown significantly over time. The Security Council, which is one of the six main "bodies" of the United Nations, consists of five permanent members (China, France, Russia Federation, the United Kingdom, and the United States of America ("P-5") and ten other members chosen by the General Assembly for a period of two years. It has always been the maintenance 


\section{QALAAI ZANISTSCIENTIFIC JOURNAL \\ A Scientific Quarterly Refereed Journal Issued by Lebanese French University - Erbil, Kurdistan, Iraq \\ Vol. (5), No (3), Summer 2020 \\ ISSN 2518-6566 (Online) - ISSN 2518-6558 (Print)}

of international peace and security, but his understanding of the essence of this mandate and the means to enforce it has changed for decades (Zara Qurashi, 2009, p. 12).

The Council placed the safety of vulnerable groups in armed conflict at the heart of its responsibility to maintain international peace and security, and the aim of its actions under Chapter VII of the Charter is to avoid immediate threats to peace and restore peace violations. The Council has unique authority to take all appropriate steps to avoid and end threats to peace and stability, including mass killings and violations of international humanitarian law, and thus is the primary tool by which states can fulfill their legal obligations to work together to end these violations. In disadvantaged societies such as women's rights under international humanitarian law, Council actions have impact a paradigm change in vulnerable group. For example, resolutions 827 (1993) and 955 (1994) establishing the International Criminal Tribunal for the former Yugoslavia (the International Criminal Tribunal for the Former Yugoslavia) and the International Criminal Tribunal for Rwanda, respectively, have given rise to historical precedents and expanded women's right to justice due to sexual assault including rape, (Janet Benshoof, 2014, p.68).

However, when dealing with this issue, the Security Council plays a historical role in recognizing that vulnerable protection groups such as children in armed conflict are an important issue of peace and security that needs effective and decisive action. The development of the monitoring and reporting system to monitor six serious violations called for by Security Council resolution 1612 (2005) was widely welcomed as a major step forward. These violations are: killing or maiming of children; recruitment or use of child soldiers; attacks on schools or hospitals; rape or severe sexual exploitation of children; abduction of children and denial of humanitarian access to children (Simona Drenik, 2009, p.5).

The annual report of the United Nations Secretary-General to the Security Council for Children and Armed Conflict on the implementation of, inter alia, Security Council Resolution 1612 (2005), was issued on April 22, 2009. The Security Council also 


\section{QALAAI ZANISTSCIENTIFIC JOURNAL \\ A Scientific Quarterly Refereed Journal Issued by Lebanese French University - Erbil, Kurdistan, Iraq \\ Vol. (5), No (3), Summer 2020 \\ ISSN 2518-6566 (Online) - ISSN 2518-6558 (Print)}

discussed this during an open debate on children and armed conflict on 29 April 2009. The Secretary-General's report records grave violations against children in 20 cases of concern, including Afghanistan, Burundi, the Central African Republic, Chad, Colombia and Cote D'ivoire. In addition, the Democratic Republic of the Congo, Georgia, Haiti, Iraq, Myanmar, Nepal and Occupied Pascal, the study specifically indicates that government and non-state actors are committing serious violations of vulnerable groups such as children (UN, 2019).

\subsection{The role United Nation of the Security Council (UNSC)}

In these circumstances, the role of the United Nations of the Security Council comes in light of maintaining international peace and security under the United Nations Charter. For example, the United Nations Security Council (the "Security Council") has had a leading role in investigating massacres since the end of the Cold War. However, the UN Security Council only agreed to investigate atrocities committed in 11 of the 92 countries that suffered atrocities during this time (Christodoulos Kaoutzanis, 2020, p. vii). The Security Council has recently become more effective in supporting human rights, especially in situations of armed conflict, by implementing economic and political sanctions, and more precisely, in establishing courts, as is the case with Yugoslavia and Sierra Leone (Dieter Fleck, 2009, p 275).

Protection of vulnerable groups is the primary language of any Security Council resolution authorizing a peace process in which the lives of vulnerable groups are at risk and have certainly become a "normative commitment" in peace operations today (Cristina Gabriela Badescu, 2011, p. 89). If violations of international humanitarian law are so severe that they endanger peace, the Council is empowered to order intimidation through non-military or military measures. Unless the Council decides to implement compliance measures, the prohibition of interference in matters that are subject to the domestic jurisdiction of each State will not apply. The Genocide Convention, the four Geneva Conventions, and the First Additional Protocol provide for national intervention in the event of serious violations against protected persons, 


\section{QALAAI ZANISTSCIENTIFIC JOURNAL \\ A Scientific Quarterly Refereed Journal Issued by Lebanese French University - Erbil, Kurdistan, Iraq \\ Vol. (5), No (3), Summer 2020 \\ ISSN 2518-6566 (Online) - ISSN 2518-6558 (Print)}

i.e. intentional killing, abuse, inhuman treatment, massive destruction and seizure of property, unless military necessity justifies it (Sydney D. Bailey, 1994, p.88).

Since the United Nations Security Council bears primary responsibility under the Charter for the maintenance of international peace and security, it is important to take the steps required to restore international peace and security. Article 39 states that:

"The Security Council shall determine the existence of any threat to the peace, breach of the peace, or act of aggression and shall make recommendations, or decide what measures shall be taken in accordance with Articles 41 and 42, to maintain or restore international peace and security"( Françoise Joly,2014).

One of the main goals of the United Nations, as mentioned above, is to promote and encourage respect for human rights with protection of human and fundamental freedoms for all without distinction as to race, sex, language, or religion. This is expressed as: (UN Charter, 1945, art 1 (3).

"With a view to the creation of conditions of stability and well-being which are necessary for peaceful and friendly relations among nations based on respect for the principle of equal rights and self-determination of peoples, the United Nations shall promote: universal respect for, and observance of, human rights and fundamental freedoms for all without distinction as to race, sex, language, or religion" (UN Charter, 1945, art 55).

\subsection{Responsibility to protect}

Protection of vulnerable groups has been a top priority in United Nations peace operations since 1999, with Security Council mandate for 14 United Nations peacekeeping operations, including security functions. Today, as part of a coordinated mission-wide effort, more than $98 \%$ of the military and police personnel working in UN peacekeeping missions around the world have a mandate to protect vulnerable groups (H. Peter Langille, 2016, p. 11). The biggest obstacle to the United Nations and the multilateral scheme is to save people's lives in urgent danger (Marie 


\section{QALAAI ZANISTSCIENTIFIC JOURNAL \\ A Scientific Quarterly Refereed Journal Issued by Lebanese French University - Erbil, Kurdistan, Iraq \\ Vol. (5), No (3), Summer 2020 \\ ISSN 2518-6566 (Online) - ISSN 2518-6558 (Print)}

O'Reilly, 2015) but the United Nations is also facing a security vacuum, with few signs of fading. An internal United Nations study by the United Nations Office of International Oversight Services on the protection of vulnerable groups reported that peacekeepers rarely respond quickly to attacks on vulnerable groups, and there is a consistent trend of reluctance to use force to defend vulnerable groups. The protective will is narrow. Defense setting and preparation for defense are also limited. National capitals and the national armed forces are reluctant to prioritize security (UN Doc. A/68/787, March 7, 2014.). With the end of the Cold War, some countries began to appeal to the principle of humanitarian intervention as a rationale for their military actions. This is especially the case with the intervention in Iraq in 1991. The United States, the United Kingdom, and France first laid the foundations for their work - air strikes aimed at imposing no-fly zones in northern and southern Iraq to ensure humanitarian aid is distributed over the traditional idea of a council mandate. However, Resolution 688 never allowed (SC Res 688, 1991.0. indirectly, the use of force. This is evident, among other things, in the fact that the Council refrained from referring to Chapter Seven that the identification of the "peace threat" was related to the cross-border impact of refugee flows and human rights violations committed against the Kurdish minority (Anne-Sophie Massa, 2009, p.11).

The new Responsibility to protect theory, in detail, goes beyond the duty of the international community to deter and avoid four important international crimes under international law - genocide, war crimes, crimes against humanity, and ethnic cleansing - exceeding existing legal mandates of international humanitarian law and state law an obligation. Responsibility to protect focuses on the responsibility of every country to protect its citizens, and defines the duty of the international community to protect vulnerable groups from these serious crimes (Janet Benshoof, 2014, p. 17).

The responsibility to protect provides a mandatory basis for continuing the discussion beyond the controversial use of force on humanitarian grounds to resolve the protection of victims of collective atrocities, as the responsibility to protect from research emerges to overcome the dilemma of intervention, the proposals address many of the contentious concerns raised by the idea of humanitarian intervention. 


\section{QALAAI ZANISTSCIENTIFIC JOURNAL \\ A Scientific Quarterly Refereed Journal Issued by Lebanese French University - Erbil, Kurdistan, Iraq \\ Vol. (5), No (3), Summer 2020 \\ ISSN 2518-6566 (Online) - ISSN 2518-6558 (Print)}

Consequently, it is the duty of every state to protect its people from mass killings and other grave violations of their rights. If that state is unable or unable to do above mentioned task, the state abolishes its sovereignty, and the international community has a duty to defend it. Therefore, two elements of the responsibility to protect system are essential: state sovereignty as an obligation, and international accountability in desperate circumstances (Cristina Gabriela Badescu, 2011, p. 16).

The 2001 report outlined three elements of the broader responsibility for preserving the parachute, namely liability for prevention, responsibility for response and responsibility for restoration. The report consists of separate chapters on the need to avoid gross violations of human rights, the responsibility to respond to them as they arise, and the responsibility to rebuild after any military intervention, (Cristina Gabriela Badescu, 2011, p. 17).

Fifteen years ago, world leaders agreed at the 2005 World Summit on a common duty to protect vulnerable groups. They have not yet reached agreement on whether to protect the vulnerable groups or not (H. Peter Langille, 2016, p. 11).

In the aftermath of the 2005 World Summit, pressure campaigns focused on persuading the Security Council to reaffirm the responsibility to protect civilians against genocide and other crimes against humanity. In December 2005, open consultations were held on a thematic draft resolution on the security of vulnerable groups in armed conflict. The Russian and Chinese reluctance was eventually resolved in April 2006 after four months of deadlock due to the Council's difficulties in reaching agreement on a language related to the responsibility to protect. The result was Security Council Resolution 1674 on the Defense of Vulnerable Persons, adopted on 28 April 2006, "reaffirms the provisions of paragraphs 138 and 139 of the World Summit Outcome Document regarding the responsibility to protect populations from genocide, war crimes, ethnic cleansing and crimes against humanity" (Cristina Gabriela Badescu, 2011, pp. 121 -122.).

International humanitarian NGOs have played and will continue to play a major role on every measure in clarifying humanitarian standards, and influencing discussions 


\section{QALAAI ZANISTSCIENTIFIC JOURNAL \\ A Scientific Quarterly Refereed Journal Issued by Lebanese French University - Erbil, Kurdistan, Iraq \\ Vol. (5), No (3), Summer 2020 \\ ISSN 2518-6566 (Online) - ISSN 2518-6558 (Print)}

about humanitarian action. The security of vulnerable people, especially women and children in armed conflict, is now at the center of the international political debate, including the security of mass killings and the types of human rights violations that shake the moral conscience of humankind. Recent examples include Security Council resolutions 1674 and 1888 dealing with the defense of vulnerable groups; and Resolution 1706 authorizing the deployment of United Nations Mission in the Sudan (UNMIS) peacekeepers in Darfur (Melissa Labonte, 2013, p. 8).

The responsibility to protect and protect weak society policy focuses on international humanitarian law, both of which focus on individual security. All responsibility for the protection and protection mechanisms of a vulnerable society accepts the primary duty of states to protect their populations. In addition, neither of the two objectives can be considered equal to the use of military force. In addition, the use of force with a Chapter 7 mandate is envisaged only in severe cases (Cristina Gabriela Badescu, 2011, p. 25).

Therefore, the effective application of the responsibility to protect the vulnerable groups depends on many factors at the same time. These include the existence of one of the four forms of collective atrocities that cause responsibility for protection, the willingness of participating states to risk the lives of their soldiers in order to "protect strangers", appropriate preparation and doctrine to meet the unique needs of nonpermissive conflict environments, and appropriate and effective response capabilities (Secretary General, 2009, A/63/677, para. 40).

The Secretary-General encourages states to become parties to the applicable international human rights instruments, international humanitarian law and refugee law, as well as to the Rome Statute of the International Criminal Court. The Rome Statute of 2008 is of particular importance because it seeks to punish the crimes mentioned in the paragraphs and thus avoid them. Results sheet 138 and 139 (Peter Hilpold, 2014, p. 19)

The Council adopted Resolution 1706 on August 31, 2006 which called for the rapid deployment of UN peacekeepers in Sudan. The resolution also clearly indicated the 


\section{QALAAI ZANISTSCIENTIFIC JOURNAL \\ A Scientific Quarterly Refereed Journal Issued by Lebanese French University - Erbil, Kurdistan, Iraq \\ Vol. (5), No (3), Summer 2020 \\ ISSN 2518-6566 (Online) - ISSN 2518-6558 (Print)}

responsibility to protect, by reaffirming the provisions of Resolution 1674 and paragraphs 138 and 139 of the text of the 2005 World Summit Outcome. Like all previous embodiments of the responsibility to protect, that makes these references to the responsibility to protect important the most substantive progression of the concept is the legal force of Security Council resolution (Melissa Labonte, 2013, p. 28).

In the eighth open debate on the security of vulnerable groups in armed conflict in November 2009, the Security Council unanimously adopted Resolution 1894, which reaffirms "the relevant provisions of the 2005 World Summit Outcome Document regarding the protection of civilians in armed conflict, including paragraphs 138 and 139 thereof regarding the, (General Assembly resolution A/RES/60/ 1), 2005, paras.138-39). "Responsibility to protect populations from genocide, war crimes, ethnic cleansing and crimes against humanity" This was the third time that a Security Council resolution had referred to the responsibility to protect that the Member States of the United Nations refer to the responsibility to protect in public statements before the Security Council regarding the defense of mainly vulnerable groups (Cristina Gabriela Badescu, 2011, p. 126).

\section{Conclusion and Resulting}

1- International humanitarian law and the United Nations' organization of their structures remain the modest response provided by international law during times of armed conflict. Today, in the absence of a centralized organizational structure, international law enforcement is always exceptional. The desire and willingness to abide by the laws are fully in the possession of the combatants, and supervisory procedures are based on their agreement and goodwill alone.

2-International humanitarian law and a one-state framework are ideally adapted to immediate monitoring and efforts to provide protection and immediate support to victims of armed conflict. The goal is to reach all those affected by armed conflict.

3- Though, international humanitarian law requires political support to get a chance to succeed. If the interests of the victims so warrant, then the states parties to the 


\section{QALAAI ZANISTSCIENTIFIC JOURNAL \\ A Scientific Quarterly Refereed Journal Issued by Lebanese French University - Erbil, Kurdistan, Iraq \\ Vol. (5), No (3), Summer 2020 \\ ISSN 2518-6566 (Online) - ISSN 2518-6558 (Print)}

Geneva Conventions will by law resort to their obligation to "ensure respect" for international humanitarian law under the four Geneva Conventions, common article (1). Humanitarian law calls on governments, through the United Nations, to take diplomatic measures, individually and collectively, to compel warring parties to comply with their principles.

4- The Security Council seeks to improve the security of the vulnerable groups on the ground by mandating peacekeeping operations to undertake security activities or by trying to create a political climate that enhances the delivery of humanitarian assistance. Military means may be the only solution, in unusual situations, to avoid endless killings. As in the decisions essentially taken by these political bodies, it is not even possible to confirm the existence of an objective approach, and in particular, "responsibility to protect" remains an intentionally vague term.

5-In the face of systematic violations by opposing parties to the simplest laws, and the inability or unwillingness of the international community to take bolder steps to stem abuses or even conflict, humanitarian action unrelated to any political agenda remains often the only solution. Less for conflict victims Using humanitarian action as a political tool and integrating it into the strategy makes humanitarian operations subject to the political and military objectives of the conflict, thereby reducing the humanitarian protection of victims.

6-It is clear that the duty of defense as a concept has become rooted in external relations, not as a legal requirement. It can be said that one aspect of the international legal obligation of states is to prevent vulnerable groups on a large scale from falling victim to armed conflict. According to the principle of proportionality in international humanitarian law, a balance must be struck between a military advantage and disadvantaged groups must be avoided. It can be said that this clause of the duty to protect applies this legal concept to the decision to start an armed conflict for the purposes of human security. The responsibility to protect reflects a new way of thinking about mass killings, involves responsibilities owed to both individuals and 


\section{QALAAI ZANISTSCIENTIFIC JOURNAL \\ A Scientific Quarterly Refereed Journal Issued by Lebanese French University - Erbil, Kurdistan, Iraq \\ Vol. (5), No (3), Summer 2020 \\ ISSN 2518-6566 (Online) - ISSN 2518-6558 (Print)}

governments, and represents a change in customary international law. As a flexible rule, responsibility to protect now represents a stage in treaty practice or drafting.

7-The duty to protect arose as a result of the need to fill this clear moral void in ways that address the needs of victims in situations of mass atrocities. The adoption of the Responsibility to Protect 2005 was a major political and normative change that affects the way in which states' roles are addressed, as set out in the United Nations Charter.

8-The study collected the legal structure as stipulated in international law to protect vulnerable groups from mass victims. This analysis outlines the rules laid down by international humanitarian law, and treaties with UN resolutions to protect vulnerable groups from the influence of armed groups; but thousands of vulnerable groups are intentionally targeted by armed groups. The greatest challenge to imposing the legal system is the lack of adequate infrastructure combined with a lack of political will to enforce humanitarian law that provides comprehensive protection to vulnerable groups from massacres.

\section{Recommendation and suggestions}

1-The new changes in the international relation bring the fact that the international community cannot stand idly by because armed groups and states have repeatedly violated international humanitarian law violations. It is therefore proposed to establish the "Safe heaven" Foundation under the mandate of the United Nations to prevent further genocide against vulnerable groups for example (Yazidi) minorities, put an end to the policies of discrimination against them and grant freedom of assembly in compliance with international instruments.

2-It is also proposed that the international community ask the Security Council as an alternative to establishing an ad hoc tribunal such as the former Yugoslavia and Rwanda to try crimes against vulnerable groups such as (minorities: Yazidis and Christians) Establishing this court will be less time-consuming and more cost-effective than the more automatic ICC system, which will take a long time to achieve goals. 


\section{QALAAI ZANISTSCIENTIFIC JOURNAL \\ A Scientific Quarterly Refereed Journal Issued by Lebanese French University - Erbil, Kurdistan, Iraq \\ Vol. (5), No (3), Summer 2020 \\ ISSN 2518-6566 (Online) - ISSN 2518-6558 (Print)}

3-The scarcity of current analyzes of the conflict situation in Iraq shows the need for more studies, especially those that focus directly on these women and children. Research perspectives should include the following: comprehensive analyses of the situations of vulnerable groups, including violence, rape, enslave the psychosocial and health impact on vulnerable groups by ISIS in Syria and Iraq.

4-All countries should be expected to include dilemmas in the protection of vulnerable groups, so that officers, in particular, become aware of the types of decisions that they may have to make and the legitimacy of those decisions. These same activities should open to external auditing. Publishing is not enough, even at the ICRC.

5-All states will be legally obligated to consider impartial humanitarian assistance to vulnerable groups, regardless of the designation of the case. Although humanitarian aid and aid workers may enter in practice to the parties to the conflict, this should not be legal. Moreover, if humanitarian organizations are legally allowed to provide assistance, they may face less opposition on the ground.

(When writing references, internationally, you have to write them alphabetically and do not divide them between "books, case, PhD and MA thesis etc". I have changed the references format, so I do hope you are comfortable with that.)

\section{References}

- Alice Edwards, (2009) Displacement, Statelessness and Questions of Gender Equality under the Convention on the Elimination of All Forms of Discrimination against Women, UNHCR, Geneva, Switzerland.

- Anne Orford, (1996), the Politics of Collective Security, Michigan Journal of International Law, Vol.17, No. 2.

- Anne-Sophie Massa, (2009), Does Humanitarian Intervention Serve Human Rights The Case of Kosovo, Amsterdam Law Form, vol.1, No. 49.

- Audrey R. Chapman \& Benjamin Carbonetti, (2011), Human Rights Protections for Vulnerable and Disadvantaged Groups: The Contributions of the UN Committee on Economic, Social and Cultural Rights, Human Rights Quarterly, Vol. 33. 
- Chandrima Chatterjee \& Gunjan Sheoran, (2007), The Ctr. for Enquiry into Health and Allied Themes (CEHAT ), Vulnerable Groups in India, available at http://www.cehat.org/humanrights/

- Christodoulos Kaoutzanis, (2020), the UN Security Council and International Criminal Tribunals: Procedure Matters, Stamford, USA, Springer.

- Consideration of Reports Submitted by States Parties under Articles 16 and 17 of the Covenant: Concluding Observations of the Committee on Economic, Social and Cultural Rights: Iraq, adopted 4 Dec. 1997, U.N. ESCOR, Comm. on Econ., Soc. \& Cult. Rts., 17th Sess., 52d mtg., 1 8, U.N. Doc. E/C.12/l/Add.17 (1997).

- Cristina Gabriela Badescu, (2011), Humanitarian Intervention and the Responsibility to Protect 'Security and human rights, New York. Routledge.

- David P. Forsythe \& Barbara Ann J. Rieffer-Flanagan, (2007), The International Committee of the Red Cross A neutral humanitarian actor, New York, Routledge.

- Dieter Fleck, (2009), the Handbook of International Humanitarian Law, $2^{\text {nd }} \mathrm{edn}$, New York, Oxford University Press.

- Emily Crawford \& Alison Pert, (2015), International humanitarian law, United Kingdom, Cambridge University Press.

- Francesca Ippolito \& Sara Iglesias Sánchez, (2015), Protecting Vulnerable Groups, in the European Human Rights Framework, United Kingdom, Hart Publishing.

- -Françoise Joly, (2014), the Responsibility to Protect: From Doctrine to Practice 'R2P' and Protection of Civilians, thesis and dissertation, Dublin City University.

- Geoffrey Best, (1994), War and Law since 1945, New York, Oxford University Press.

- Gerald Alditya Bunga, (2017), the Protection of Women in Armed Conflict, Yustisia Journal, Vol.6 No. 2.

- Global Centre for the Responsibility to Protect, (2020), Populations in Iraq suffered mass atrocities and violations of international law by various armed forces and nonstate armed groups in the context of mass protests during 2019 and a 2014-2017 conflict. https://www.globalr2p.org/countries/iraq/

- H. Peter Langille, (2016), Developing a United Nations Emergency Peace Service, $1^{\text {st }}$ edn, United Kingdom, Palgrave Macmillan.

- Haidi Willmot, Ralph Mamiya, Scott Sheeran, \& Marc Weller, (2016), protection of civilians, $1^{\text {st }}$ dn, United Kingdom, oxford university press.

- Hans-Peter Gasser, (2016), The International Committee of the Red Cross', Max Planck Encyclopaedia of International Law (Online, Oxford University press; https://opil.ouplaw.com/view/10.1093/law:epil/9780199231690/law9780199231690-e310\#law-9780199231690-e310-div1\%E2\%80\%931

- International Court of Justice, (Nicaragua v. United States of America), 1986 ICJ 14, Merits Judgment, 1986, p.220. 
- International Review of the Red Cross humanitarian debate: (2015), law, policy, action, Principles guiding humanitarian action, 97 ICRC 897/8, 2.

- Janet Benshoof, 'Women, Peace, and Security', in Jared Genser And Bruno Stagno Ugarte, (2014), The United Nations Security Council In The Age Of Human Rights, $1^{\text {st }}$ edn, USA, Cambridge University Press.

- Judith Gail Gardam \& Michelle J Jarvis, (2011), Women, Armed Conflict and International Law, Hague, Netherland, Kluwer Law International Publisher.

- Judith Gail Gardam, (1992), Non-Combatant Immunity as a Norm of International Humanitarian Law, Boston, London, Nijhoff.

- Kelly D.H., (2013), Why Does Disability Make People More Vulnerable to Domestic Abuse'? 23 October 2013, available at https://www.thefword.org.uk/2013/10/why does_disabi/, (accessed 10 sept 2019); 'Preventing Elder Abuse and Neglect in Older Adults', available

http://www.healthinaging.org/resources/resource:preventingelder- abuse-andneglect-in-older-adults/, (accessed 10 sept 2019).

- Lindsay Moir, the Law of Internal Armed Conflict, (2004), United Kingdom, Cambridge University Press.

- Marie O'Reilly, (2020), Nothing Is More Important than Saving Lives, Q and A with Michael Doyle', IPI, Global Observatory, March 26, 2015. Available: http://theglobalobservatory.org/2015/03/doyle-united-nations-multilateralism

- Melissa Labonte, (2013), Human Rights and Humanitarian Norms, Strategic Framing, and Intervention 'Lessons for the responsibility to protect', New York, Routledge,

- Payam Akhavan, (1996), the International Criminal Tribunal for Rwanda: The Politics and Pragmatics of Punishment, the American Journal of International Law, Vol.90, No. 3.

- Peter Hilpold, (2015), Responsibility to Protect (R2P) A New Paradigm of International Law? Leiden, the Netherlands, Koninklijke Brill.

- Peter Maurer, The Evolution in the Legal Protection of Victims of Armed Conflict, in book by Terry D. Gill, (2014), Yearbook of International Humanitarian Law, United Kingdom, Cambridge University Press, Springer, Volume 17.

- Robert Kolb \& Richard Hyde, (2008), an Introduction to the International Law of Armed Conflicts, Portland, USA, Hart Publishing.

- Roland Paris, (2014), The Responsibility to Protect' and the Structural Problems of Preventive Humanitarian Intervention, International Peacekeeping, Vol. 21, No.5.

- Simona Drenik, (2009) Protection of Children in Armed Conflict under Customary International Humanitarian Law, (A Comment to the 2005 ICRC Study on Customary IHL), Slovenian Law Review, Vol.6. No.165. 


\section{QALAAI ZANISTSCIENTIFIC JOURNAL}

A Scientific Quarterly Refereed Journal Issued by Lebanese French University - Erbil, Kurdistan, Iraq

Vol. (5), No (3), Summer 2020

ISSN 2518-6566 (Online) - ISSN 2518-6558 (Print)

- Sydney D. Bailey, (1994), the UN Security Council and Human Rights, United Kingdom, Macmillan.

- Terry D. Gill, (2014), Yearbook of International Humanitarian Law, Volume 17.

- The definition of the adjective vulnerable can be found at http://www.merriamwebster. com/dictionary/vulnerable, (accessed 18 June 2019).

- U C Jha (Retd), Ratnabali, (2017), The Law of Armed Conflict An Introduction, Vij Books India, Pvt Ltd, India.

- Ursula Kilkelly \& Ton Liefaard, (2019), International Human Rights of Children, Singapore, Springer Nature Singapore Pte Ltd.

- Veronique Zanetti, Women, War, and International Law, in book Igor Primoratz, (2007), Civilian Immunity in War, , New York, Oxford University Press.

- Zara Qurashi, (2009), Violence against Women during Armed Conflicts, New York, Routledge.

\section{Conventions}

Hague Regulations, (1907).

Geneva Conventions I, (1949).

Geneva Conventions II, (1949).

Geneva Conventions III, (1949).

Geneva Conventions IV, (1949).

Additional Protocol I, (1977).

Convention on the Rights of the Child, (1989).

\section{United Nations documents and resolutions:}

UN Charter, (1945).

UN Doc. A/68/787, March 7, 2014.

SC Res 688, 1991.http://www.un.org/children/conflict/english/index.html (visited on 3 Jun 2019).

Secretary General in his report, (2009) 'Implementing the Responsibility to protect', A/63/677, para. 40. 


\section{QALAAI ZANISTSCIENTIFIC JOURNAL}

A Scientific Quarterly Refereed Journal Issued by Lebanese French University - Erbil, Kurdistan, Iraq

Vol. (5), No (3), Summer 2020

ISSN 2518-6566 (Online) - ISSN 2518-6558 (Print)

General Assembly resolution A/RES/60/ 1), 24 October 2005, paras. 138-39.

\section{Website}

\section{https://www.merriam-webster.com/dictionary/vulnerable\%20groups}

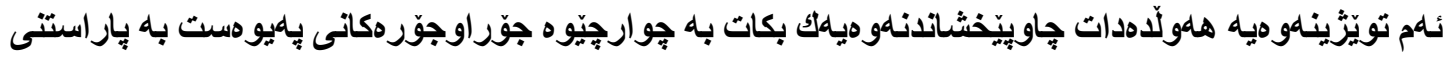

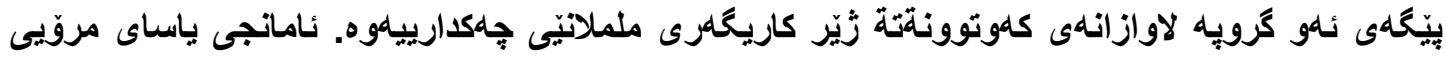

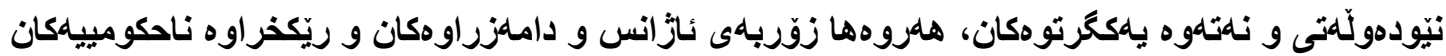

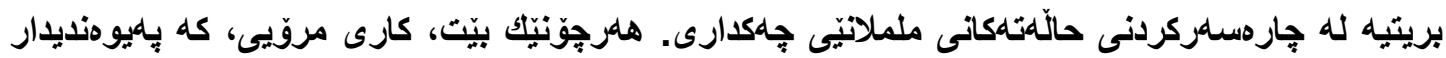

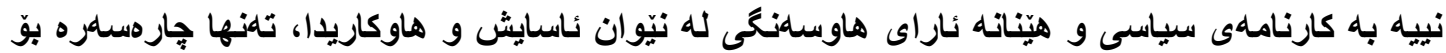

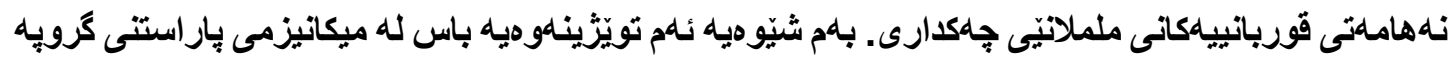

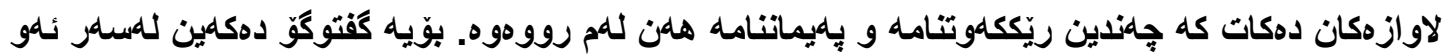

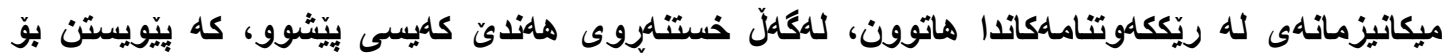

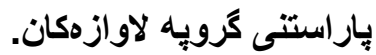

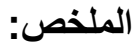

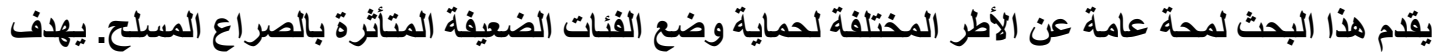
القانون الاولي الإنساني والأمم المتحدة ومختلف المؤسسات والوكالات والمنظمات غير الحكومية إلى حل حالات النزاع المسلح. ولكن العمل الإنساني، الأي هو غير مرتبط بأي أجندة سياسية و وبتحقيق التوازن بين

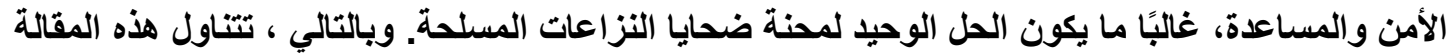

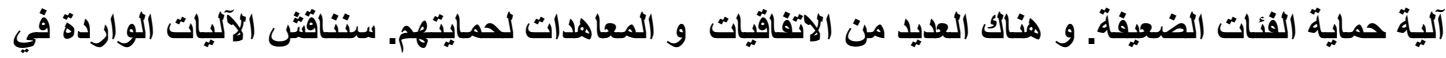
الاتفاقيات والقرارات الدولية مع تناول بعض الحالات السابقة و الضرورة لحماية الفئات الضعيفة:

Key words: vulnerable groups, protection, armed conflict, international humanitarian law, united nation organization. 